Jurnal Konstruksi Hukum | ISSN: 2746-5055

Vol. 2, No. 2, Mei 2021, Hal. 412-417| Tersedia online di

https://www.ejournal.warmadewa.ac.id/index.php/jukonhum

DOI: https://doi.org/10.22225/jkh.2.2.3265.412-417

\title{
KONSINYASI DALAM PENGADAAN TANAH BAGI PEMBANGUNAN UNTUK KEPENTINGAN UMUM
}

\author{
Anak Agung Istri Pradnya Mita Iswari, I Nyoman Alit Puspadma, Luh Puru Suryani \\ Fakultas Hukum Universitas Warmadewa, Denpasar-Bali, Indonesia \\ pradnyamita12@gmail.com, alitnotarisbadung@yahoo.com, putusuryani099@gmail.com
}

\begin{abstract}
Abstrak
Pengadaan tanah untuk kepentingan Generik bisa di buat menempuh dua sistem yaitu pembebasan kewenangan pada lahan serta pembatalan kewenangan pada lahan, akan tetapi Negara ada keharusan memberi konsekuensi berupa ganti kerugian (konsinyasi). Penelitian ini mencakup tentang proses pengadaan tanah untuk kepentingan umum menurut Undang-Undang Nomor 2 tahun 2012, serta untuk mengetahui tata cara penitipan ganti rugi (Konsinyasi) untuk kepentingan umum di pengadilan dalam rangka pengadaan tanah. Metode penelitian yang digunakan adalah penelitian hukum normatif dan pendekatan masalah dengan menelaah peraturan perundangundangan. Hasil penelitian menunjukkan bahwa di dalam UU No. 2 tahun 2012 terdapat prosedur menyediakan lahan yang meliputi proses perencanaan, persiapan, pelaksanaan dan penyerahan hasil. Kemudian, mengenai Penitipan ganti kerugian di Pengadilan terdapat 7 tata cara seperti permohonan harus diajukan secara tertulis dengan menggunakan Bahasa Indonesia, ditandatangani pemohon dan dilampiri dokumen pendukung penagih melunasi uang muka anggaran melewati bank, dilengkapi dengan pendaftaran pemohon, negosiasi pelunasan, pemutusan serta pencadangan uang kompensasi serta pencabutan uang kompensasi.
\end{abstract}

Kata kunci: Kepentingan Umum; Konsinyasi; Pengadaan Tanah.

\begin{abstract}
Land acquisition for generic interests can be made through two systems, namely the release of authority over land and cancellation of authority over land. However, the State must provide consequences in the form of compensation (consignment). This research covers the land acquisition process for public interest according to Law Number 2 of 2012, as well as to find out the procedures for depositing compensation (consignment) for public interest in court in the context of land acquisition. The research method used is normative legal research and problem approach by examining statutory regulations. The results showed that in Law no. 2 of 2012 there is a procedure for providing land which includes the process of planning, preparation, implementation and submission of results. Then, regarding the custody of compensation in court, there are 7 procedures such as the application must be submitted in writing in Indonesian, signed by the applicant and attached with supporting documents for the collector to pay the down payment through the bank, completed with applicant registration, negotiation of repayment, termination and reserve of compensation money. as well as revocation of compensation money.
\end{abstract}

Keywords: Public Interest; Consignment; Land Acquisition

\section{PENDAHULUAN}

Lahan bagi individu mempunyai peran akan sangat berpengaruh bagi individu, baik ketika masih bernyawa bahkan sampai meninggal dunia. Ketika masih hidup, manusia membutuhkan tanah unruk di bangun rumah sebagai tempat tinggal atau hunian, manusia melaksanakan aktivitas kehidupannya di atas tanah, manusia mengusahakan atau memanfaatkan tanah untuk keperluan pertanian, perikanan, peternakan dan perkebunan (Harjiyatni \& Raharja, 2014). Sedangkan, ketika meninggal dunia manusia membutuhkan tanah untuk tempat pemakaman. Tanah memiliki makna krusial pada kehidupan berindividu lantaran menerima 2 (dua) fungsi yaitu social asset dan capital asset. Untuk social asset, tanah adalah tempat pemikat keutuhan sosial pada kalangan warga Indonesia untuk hayati dan kehidupan, sedangkan sebagai capital asset, tanah merupakan faktor modal dalam pembangunan (Suyanto, 2019).

Istilah pengadaan tanah merupakan pengganti dari istilah pembebasan tanah dalam pada gunakan pada Peraturan Menteri Dalam Negeri untuk mengatur mengenai Pembebasan kewenangan atas lahan sebelumnya. Makna pembebasan hak atas lahan atau menyediakan lahan pada Peraturan Menteri Dalam Negeri mendapatkan tanggapan isu negatif sang warga dan pegiat aturan pertanahan 
(aruran agrarian) sehubung menggunakan banyaknya perseteruan yang disebabkan pada kegiatannya. Mengenai pengertian pengadaan tanah itu sendiri disebutkan dalam Keputusan Presiden Nomor 55 tahun 1993 yang terdapat dalam Pasal 1 angka 1, Peraturan Presiden Nomor 36 Tahun 2005, Peraturan Presiden Nomor 65 tahun 2006, Undang-Undang Nomor 2 Tahun 2012 dan Peraturan Presiden Nomor 71 tahun 2012 (Sugiharto, Suratman, \& Muchsin, 2015). Terdapat 3 (tiga) unsur dari arti pengadaan tanah secara luas yang terdiri dari menurut aktivitas buat menerima tanah, pada rangka pemenuhan kebutuhan huma buat pembangunan kepentingan global, hadiah kompensasi kepada yang terkena aktivitas dan divestasi interaksi aturan menurut pihak tanah kepada pihak lain (Syah, 2020).

Ketentuan mengenai konsinyasi pada bentuk penyediaan lahan buat keperluan generik yang pada arahnya terdapat gedung, tumbuhan, maupun barang sangat berkaitan pada lahan yang nihil ditemukan kependudukannya sang pekerja pengelola yang menginginkan lahan, hal ini bisa mengakibatkan kesusahan pada memenuhi titip jual tadi (Soerodjo, 2003). Sebagai alur keluarnya, pekerja pengelola berusaha mendapatkan kependudukan pemilik berwenang atas lahan yang nihil di ingat kependudukannya pada media cetak dan elektronik dengan harga pencantuman iklan di tanggung sang instansi pengelola yang menginginkan lahan (Aartje, 2017). Jika pada tempo waktu 30 (tiga puluh) hari sehabis penempatan pamflet tadi nihil keberadaan kependudukannya, atau nihil keinformasiannya, pekerja pengelola sangat membutuhkan lahan terkini cukup mengkonsinyasikan uang kompensasi pada Mahkamah Nagari domestik. Apabila, sebelumnya ada informasi pada tempo 30 (tiga puluh) hari sehabis penetapan pamflet, pekerja yang membutuhkan lahan harus memulai musyawarah sang para pihak yang dibimbing sang panitia penyedia lahan untuk tidak mengubah wujud dan membludaknya kompensasi. Walaupun setengah besar pemegang yang memiliki kewenangan atas lahan pada suatu daerah sudah menerima wujud atau membludaknya kompensasi yang dianjurkan sang instansi pemerintah yang membutuhkan lahan, tersisa tunggal maupun sebagian pegang kewenangan dari lahan yang asing sudut pandang tanahnya tercatat di daerah tidak mengesahkan bentuk serta membludaknya kompensasi. Oleh karena itu, atas tunggal maupun sebagian pejabat pernilik lahan ini, modal kompensasinya tak dibetulkan untuk dikonsinyasikan sang pekerja pemerintah yang membutuhkan lahan (Aartje, 2017).

Berdasarkan pada pemaparan latar belakang di atas, maka penelitian ini dirumuskan untuk mengetahui proses pengadaan tanah untuk kepentingan umum menurut Undang-Undang Nomor 2 tahun 2012, serta untuk mengetahui tata cara penitipan ganti rugi (konsinyasi) untuk kepentingan umum di pengadilan dalam rangka pengadaan tanah.

\section{METODE PENELITIAN}

Tipe penelitian yang digunakan pada penelitian ini adalah jenis penelitian hukum normatif yang dilakukan dengan cara meneliti bahan pustaka yang ada ataupun yang berkaitan dengan materi penelitian yang diambil (Soekanto \& Mamudji, 2006). Mengenai pendekatan masalah yang dipakai pada riset studi ini yaitu pemahaman secara perundang-undangan seperti pemahaman yang dilaksanakan serta rnenengok seluruh perpu yang berkaitan pada permasalahan yang masih dihadapi, serta memahami kepadatan sekitar UUD pada UU maupun sekitar UU yang tunggal maupun yang lainnya. Adapun mengenai sumber bahan hukum yang digunakan dalam penelitian ini terdapat 2 (dua) sumber bahan hukum yaitu sumber bahan hukum primer yang mencangkup perpu seperti UUD NRI 1945, UU No 5 tahun 1950, UU No 20 tahun 1961, UU No. 2 tahun 2012, Perpres No 71 tahun 2012, dan Kebijakan Mahkamah Agung No. 3 tahun 2016, Sedangkan sumber bahan hukum sekunder yang digunakan berupa Kamus Ensiklopedia yang berkaitan dengan materi penelitian yang diambil. Mengenai teknik pengumpulan bahan hukum dalam penelitian ini dilakukan dengan cara seperti melakukan klasifikasi, pencatatan, membaca serta melakukan sisternatika terhadap bahan-bahan hukum yang telah terkumpul yang berkaitan dengan materi penelitian ini. Sedangkan mengenai analisa bahan hukum ini disajikan secara deskriptif analis (suatu cara analisis bahan hukum dengan menyusun kalimat secara sistematis sehingga memperoleh sebuah simpulan yang tepat dan benar secara logis dan ilmiah) (Ahmad, 2008). 


\section{HASIL DAN PEMBAHASAN}

\section{Proses Pengadaan Tanah untuk Kepentingan Umum Menurut Uodang-Undang Nomor 2 Tahun 2012}

Penyedia lahan untuk keperluan global adalah salah satu aktivitas dalam hal menyajikan lahan untuk keperluan warga/global demi penggunaan rencana penyusunan yang dilaksanakan sang pemerintah maupun instansi yang membutuhkan lahan. Dalam UU No 2 tahun 2012 mengenai menyediakan lahan bagi pembangunan untuk kepentingan generik tercantum jalannya dari pembebasan lahan untuk keperluan generik menurut UU No 2 Thn 2012 sebagai berikut:

1. Proses Perencanaan

Dalam proses perancangan pembebasan lahan di landaskan pada RTRW dan mengutamakan penyusunan yang rnencangkup rancangan penyusunan tempo menengah, rancangan penting dan rancangan oprasi instansi yang berkaitan. Mengenai proses perancangan ini dibuat dalam bentuk dokumen perencanaan yang selanjutnya diserahkan oleh instansi yang memerlukan lahan kepada Gubernur yang melingkup wilayah tanah itu berada, tercantum dalam Pasal 14 ayat (1) dan (2) Undang-Undang Nomor 2 tahun 2012. Sedangkan lembaga yang terkait dengan proses ini mencangkup instansi yang memerlukan tanah, instansi teknis terkait dan lembaga profesional.

2. Proses Persiapan

Dalam proses persiapan, Gubernur membentuk tim persiapan dalam waktu paling lama 10 hari kerja yang beranggotakan Bupati/Walikota, Satuan Kerja Perangkat Desa (SKPD) provinsi yang berkaitan, instansi yang memerlukan tanah dan instansi yang terkait lainnya, adapun tugas dari rim persiapan ini seperti melaksanakan pemberitahuan rencana pembangunan, melakukan pendataan awal lokasi rencana pengadaan, melaksanakan konsultasi publik rencana pembangunan, menyiapkan penetapan lokasi pembangunan dan mengumumkan penetapan lokasi pembangunan. Gubernur juga membentuk sekretariat persiapan pengadaan tanah yang berkedudukan di sekretariat daerah provinsi. Mengenai hal ini gubernur memiliki kewenangan kepada Bupati/Walikota berdasarkan pertimbangan efisien, efektivitas, kondisi geografis, sumber daya manusia dan pertimbangan lainnya. Mengenai proses persiapan tercantum dalam Pasal 17 sampai dengan Pasal 26 Undang-Undang Nomor 2 tahun 2012.

3. Proses Pelaksanaan.

Dalam proses pelaksanaan secara garis besar mencangkup:

a) pencatatan dan mengenali penguasaan, kepunyaan, penggunaan dan pemanfaatan tanah;

b) Penafsiran kompensasi;

c) kesepakatan kompensasi; dan

d) Penyerahan kompensasi

Lembaga yang memerlukan lahan mengajukan pelaksanaan menyediakan lahan kepada Ketua Pelaksana Pembebasan Lahan dengan dilengkapi dengan dokumen perancangan menyediakan lahan serta penerbitan tempat pembaharuan. Mengenai itikad penyelenggaraannya di serahkan kepada Ketua Badan Pertanahan Nasional (BPN) yang pelaksanaanya di laksanakan oleh Kepala Kantor Wilayah Badan Pertanahan Nasional (BPN) yang selaku pengarah pengelola pembebasan lahan. Mengenai proses pelaksana tercantum dalam Pasal 27 Undang-Undang Nomor 2 Tahun 2012.

4. Proses Penyerahan Hasil

Dalam proses penyerahan hasil, Pengarah Pengelola Pembebasan Lahan penyetoran perolehan penyajian lahan pada pekerja menyediakan lahan yang dilengkapi dengan informasi menyediakan lahan sangat rua 7 hari kegiatan sedari kewenangan fenornena menyediakan lahan dengan berita acara. Penyetoran tertera berwujud sebidang wilayah dan surat pembebasan tanah. Setelah itu aparat pada menghendaki lahan bisa memulai mengelola pembaharuan sehabis dilaksanakan pemberian perolehan oleh ketua pelaksana pembebasan wilayah (Hasmi, 2019).

\section{Tata Cara Penitipan Ganti Rugi (Konsinyasi) di Pengadilan dalam Rangka Pengadaan Tanah}

Mengenai ganti rugi (konsinyasi) dalam pengadaan lahan untuk keberkuasaan umum sangat tentu memberatkan pejabat kewenangan atas lahan. Lantaran kewenangan atas lahan bukan memiliki keleluasaan demi memuluskan banyaknya kompensasi pada pejabat kewenangan atas lahan (Basrah, 1974). Kompensasi lahan bukan pula memiliki alternatif berbeda melainkan mesti mengabulkan banyaknya kompensasi yang sudah pernah dititipkan pada mahkamah nagari, maka daripada perlu 
adanya Metode proses tukar kompensasi (konsinyasi ) pada Rangka penyediaan wilayah terlebih dahulu agar dapat mempersiapkan apa saja dokumen yang harus disiapkan demi mengabulkan proses tukar kompensasi tersebut sebelum diserahkan ke Mahkamah Nagari Setempat. Tata cara mengenai hal tersebut diatur dalam Peraturan Mahkamah Agung Nomor 3 tahun 2006 yang meliputi:

1. Penawaran proses tukar kompensasi dugaan selaku tersurat menggunakan logat Indonesia pada instansi yang mernerlukan lahan yang di dalamnya mencangkup semacam jati diri penagih, jati diri pihak lawan, paparan yang sebagai latar permintaan penitipan kompensasi dan hal yang dimohonkan untuk ditetapkan.

2. Penawaran proses tukar kompensasi di paraf pada penagih maupun kuasanya dan dilampiri dengan dokumen pendukung seperti bukti yang berkaitan dengan identitas pemohon, fotokopi surat keputusan tentang penetapan lokasi pembangunan yang menunjukan permohonan sebagai instansi yang memerlukan tanah,dilengkapi dengan fotokopi berupa bukti termohon sebagai pihak yang berhak atas objek pengadaan tanah, penilai publik perihal nilai kompensasi, berita acara hasil musyawarah penetapan ganti kerugian, salinan putusan pengadilan, surat penolakan termohon atas benruk atau membludaknya kompensasi, dokumen surat gugatan, surat keputusan peletakan sita, surat keterangan bank dan sertifikat hak tanggungan.

3. Mengenai saat kejadian arsip penagihan proses tukar kompensasi andaikan telah dijumlah cukup berikutnyajuru tulis menyerahkan logo peroleh arsip, andaikan penagih telah melunasi uang muka anggaran pada untuk menghimpun uang.

4. Pada registrasi permohonan diJaksanakan jika permohonan penitipan ganti kerugian sudah lengkap, memenuhi persyaratan dan telah dicatat dalam buku register konsinyasi yang telah diberi nomor. Apabila pemohon mencabut permohonan tetapi berkas permohonan belum disampaikan kepada Ketua Pengadilan, maka panitera menerbitkan akta pencabutan permohonan dan selanjutnya diberitahukan kepada pemohon disertai dengan berkas permohonan.

5. Dalam negosiasi pelunasan, dimana juru tulis mengirimkan arsip permohonan yang sudah diregistrasi kepada Ketua pengadilan, setelah itu Ketua Pengadilan menerbitkan penetapan yang memerintahkan Juru Sita Pengadilan dengan disertai 2 (dua) orang saksi untuk melakukan penawaran pembayaran kepada termohon di tempat tinggal termohon, juru sita menyampaikan langsung kepada termohon atau kuasanya kehendak untuk menawarkan sejumlah uang nilai ganti kerugian yang diajukan pemohon kepada termohon kemudian juru sita membuat berita acara tentang pemyataan kesediaan menerima atau menolak uang ganti rugi yang ditawarkan dengan ditandatangani oleh juru sita, saksi-saksi dan termohon selanjutnya apabila tidak ditandatanganinya berita acara maka, tidak mempengaruhi keabsahan berita acara. Salinan berita acara untuk menerima atau menolak uang ganti kerugian yang ditawarkan tersebut disampaikan pula kepada termohon, setelah itu juru sita melaporkan pelaksanaan penawaran pembayaran ganti kerugian kepada Ketua Pengadilan melalui panitera dengan melampirkan berita acara pemyataan kesediaan untuk menerima atau menolak uang ganti kerugian.

6. Mengenai pengesahan beserta pencadangan harta tukar kompensasi, jika seseorang menolak sejumlah uang nilai ganti kerugian yang ditawarkan untuk dibayar maka Ketua Pengadilan menetapkan hari, tanggal dan jam sidang yang akan dilaksanakan dan memerintah juru sita untuk memanggil Pemohon dan Termohon tentang pemberitahuan akan dilakukan penyimpanan terhadap uang ganti kerugian di kas Kepaniteraan Pengadilan. Setelah itu Ketua Pengadilan menerbitkan penetapan dengan amar meliputi mengabulkan permohonan pemohon, menyatakan sah dan menerima penitipan ganti kerugian, memerintahkan Panitera untuk melakukan penyimpanan uang ganti kerugian dan memberitahukannya kepada termohon tentang membebankan biaya perkara kepada pemohon. Selanjutnya Panitera membuat berita acara yang ditandatangani oleh Panitera, Pemohon dan 2 (dua) orang saksi dengan menyebutkan jumlah dan rinciannya untuk di simpan dalam kas Kepaniteraan Pengadilan sebagai uang penitipan ganti kerugian lalu salinan berita acara disampaikan pula kepada Pemohon dan Termohon, apabila ketidakhadiran termohon dalam penyerahan uang ganti kerugian tidak menghalangi dilakukannya penyimpanan uang ganti kerugian.

7. Dalam pemungutan harta proses tukar kompensasi sisi yang berkuasa menolak bentuk ganti kerugian berdasarkan musyawarah penetapan ganti kerugian, tetapi tidak mengajukan keberatan ke Pengadilan Negeri, maka ganti kerugian dapat diambil di Kepaniteraan dalam waktu yang diinginkan pada sisi yang berkuasa disaingi melalui arsip dasar-dasar pada koordinator 
perwujudan penyediaan wilayah. Sehabis itu sisi yang berkuasa melegalkan tukar kompensasi tidak terdata kebenarannya, pelaksanaan penyediaan wilayah akan meluruskan pemberitaan melalui Camat dan Lurah secara tertulis. Pada soal materi penyediaan wilayah ditempatkan runtutan pada pihak yang berkuasa, rukar kompensasi di cabut dari bagian yang berhak di sekretariat makamah sehabis ditemukannya tetapan makamah mempunyai kekuatan hukum tetap yang disercai dengan surat pengantar dari kerua pelaksanaan pengadaan. Sebaliknya bahan penyediaan wilayah yang selaku uang muka di bank tukar kompensasi boleh dicabut di sekretariatan sehabis ditemukan kecocokan pada sisi bank. Pada sebilang pemungutan kehilangan sekretariat Mahkamah, juru tulis mempersiapkan siaran agenda pemungutan uang kompensasi yang di paraf pada sisi yang berkuasa dan 2 (dua) individu bukti (Suyanto, 2019).

\section{SIMPULAN DAN SARAN}

\section{Simpulan}

Berdasarkan hasil penelitian dan pembahasan diatas dapat ditarik kesimpulan sebagai berikut:

a. Proses menyajikan lahan untuk keperluan global menurut Undang-Undang Nomor 2 Tahun 2012 terdapat 4 ( empat ) proses menyajikan lahan yang meliputi yang pertarna, proses perencanaan yang tercantum dalam Pasal 14 ayat ( 1) dan (2) Undang-U ndang Nomor 2 Tahun 2012, yang kedua proses persiapan yang tercantum dalam Pasal 17 sampai dengan Pasal 26 Undang• Undang Nomor 2 Tahun 2012, yang ketiga proses pelaksanaan yang tercanrum pada perkara 17 VU No 2 Thn 2012 dan yang keempat proses penyerahan hasil. Di dalam proses menyediakan lahan untuk kepentingan generik di alaskan dengan prinsip perundingan mufakat renggangan pemerintah dalam hat pelaksana pengadaan tanah dan pemilik tanah yang di dalam setiap proses-proses tersebut memiliki jangka waktu yang berbeda-beda hal ini dikarenakan agar dapat memberikan kepastian di dalam pelaksanaan proses pengadaan tanah itu sendiri.

b. Tata cara penitipan ganti kerugian di Pengadilan dalam rangka pengadaan tanah terdapat dalarn Peraturan Mahkamah Agung Nomor 3 Tahun 2016 yang terdiri dari permohonan tersebut harus diisikan selaku tersurat menggunakan Logat Indonesia pada instansi yang memerlukan tanah, Permohonan tersebut harus di paraf pada penagih maupun wewenangnya beserta diselipkan arsip penunjang, di dalam berkas permohonan mengenai hal tersebut harus di hitungkan cukup dan Juru Tulis memberi paraf arsip sehabis penagih melunasi uang muka anggaran memakai bank, dilengkapi dengan pendaftaran pemohon, harus adanya negosiasi petunasan, apabita pemastian serta pencadangan uang kompensasi dan yang terakhir dilengkapi dengan pengambilan uang penitipan ganti kerugian. Apabila sudah melengkapi 7 (tujuh) tata cara mengenai penitipan ganti kerugian tersebut maka dokumen dapat di limpahkan ke Pengadilan Negeri setempat.

\section{Saran}

Adapun saran yang hendak disampaikan yaitu: saran bagi pemerintah mengenai penelitian ini yakni agar pemerintah dapat lebih memahami mengenai alur yang terdapat dalam proses menyediakan lahan untuk kepentingan generik serta tata cara penitipan kompensasi (konsinyasi) di Mahkamah, agar di kemudian hari panitia atau lnstansi yang bersangkutan dengan hat ini dapat lebih memahami mengenai tugas atau tanggung jawabnya di dalam proses menyediakan lahan untuk kepentingan generik serta penitipan kompensasi pada Mahkamah sehingga proses pengadaan tanah dan penitipan ganti kerugian di Pengadilan dapat dilaksanakan lebih baik dan berjalan dengan tancar. Kemudian, saran bagi masyarakat mengenai penelitian ini yakni agar masyarakat lebih memahami mengenai alur atau jatannya suatu proses pada menyediakan lahan untuk kepentingan generik serta tata cara datam penitipan kompensasi (konsinyasi) pada Mahkamah, agar dikernudian hari tidak adanya kesalahpahaman antara instansi atau pihak yang bersangkutan dengan masyarakat mengenai hat tersebut.

\section{DAFTAR PUSTAKA}

Aartje, T. (2017). Makna Konsinyasi Pengadaan Tanah Untuk Kepentingan Umum. Jakarta: Raih Asa Sukses.

Ahmad, B. (2008). Metode Penelitian Hukum. Bandung: Pustaka Setia.

Basrah, H. (1974). Ganti Rugi Menurut Ketentuan di Dalam Buku III KUHPerdata. Medan: PT Citra Aditya Bhakti. 
Harjiyatni, F. R., \& Raharja, S. (2014). Fungsi Peradilan Tata Usaha Negara dalam Menyelesaikan Sengketa Lingkungan (Studi Gugatan Organisasi Lingkungan Hidup). MIMBAR HUKUM, 26(2), 260-274.

Hasmi, H. (2019). Dasar-Dasar Pengadaan Tanah. Jakarta: Pusdiklat Kementerian ATR/BPN.

Soekanto, S., \& Mamudji, S. (2006). Penelitian Hukum Normatif Tinjauan Singkat. Jakarta: Rajawali Pers.

Soerodjo, I. (2003). Kepastian Hukum Hak Atas Tanah di Indonesia. Surabaya: Arkola.

Sugiharto, U. S., Suratman, \& Muchsin, N. (2015). Hukum Pengadaan Tanah: Pengadaan Hak atas Tanah untuk Kepentingan Umum Pra dan Pasca Reformasi. Malang: Setara Press.

Suyanto, H. (2019). Hapusnya Hak atas Tanah Akibat Penitipan Ganti Kerugian dalam Pengadaan Tanah Untuk Kepentingan Umum. Surabaya: CV. Jakat Publishing.

Syah, M. lskandar. (2020). Pembebasan Tanah Untuk Pembangunan Kepentingan Umum. Jakarta: Jala Permata Aksara. 